NBER WORKING PAPER SERIES

\title{
CHANGES IN THE PHYSIOLOGY OF AGING \\ DURING THE TWENTIETH CENTURY
}

\author{
Robert W. Fogel \\ Working Paper 11233 \\ http://www.nber.org/papers/w11233 \\ NATIONAL BUREAU OF ECONOMIC RESEARCH \\ 1050 Massachusetts Avenue \\ Cambridge, MA 02138 \\ March 2005
}

Presented as a public lecture at Cornell University, School of Industrial and Labor Relations, Department of Labor Economics, October 18, 2004. e views expressed herein are those of the author(s) and do not necessarily reflect the views of the National Bureau of Economic Research.

(C2005 by Robert W. Fogel. All rights reserved. Short sections of text, not to exceed two paragraphs, may be quoted without explicit permission provided that full credit, including $\odot$ notice, is given to the source. 
Changes in the Physiology of Aging during the Twentieth Century

Robert W. Fogel

NBER Working Paper No. 11233

March 2005

JEL No. I11, I12, J11, J14

\begin{abstract}
$\underline{\text { ABSTRACT }}$
One way to demonstrate how remarkable changes in the process of aging have been is to compare health over the life cycles of 3 cohorts. For the first cohort, born between 1835 and 1845 (the Civil War cohort), life was short and disabilities were common even at young ages. Other factors contributing to lifelong poor health were widespread exposure to severely debilitating diseases and chronic malnutrition. Fewer of the World War II cohort, born between 1920 and 1930, died in infancy and most of the survivors have lived past age 60 without developing severe chronic diseases. Members of this cohort have experienced better health throughout their lives largely due to their lower exposure to environmental hazards before birth and throughout their infancy and early childhood. Members of the cohort born between 1980 and 1990 have a 50-50 chance of living to age 100. The average age at onset of disabilities has continued to rise, so members of this cohort can expect to remain healthy at later ages. Adopting a healthy life style early can help to prevent or postpone disability at older ages.

Robert W. Fogel

Director, Center for Population Economics

University of Chicago, Graduate School of Business

5807 S. Woodlawn Avenue

Chicago, IL 60637

and NBER

rwf@cpe.uchicago.edu
\end{abstract}


Perhaps the best way to describe changes in the process of aging during the twentieth century is to consider the life and times of three cohorts. The first cohort was born between 1835 and 1845 . This is the cohort that ended slavery by fighting the Civil War. The members of this cohort were born mainly in rural areas but they ended their lives in America's burgeoning cities. They were the first cohort to reach age 65 during the twentieth century.

The second cohort was born between 1920 and 1930, eighty-five years after the first. This is my cohort. I was born in 1926. In the year of my birth there was no television, there were no refrigerators, and commercial aviation was still a controversial dream, as was commercial radio.

Most of the members of my cohort were born in cities and have lived out their lives in cities, although some of them have been lucky enough to buy summer homes in those rural areas that the first cohort fled. We were much better educated than the first cohort: about 65 percent of us completed high school and 15 percent received college degrees. We lived through the dark days of the Great Depression of the 1930s and the rise of Nazism. Some 12 million of us fought in World War II and another 10 million, mainly women, worked in the war industries. These 22 million represented a third of the American labor force. As with the war in Iraq, the United States bore most of the cost of the war. Shortly after Pearl Harbor, President Roosevelt pledged to turn the United States into an "Arsenal of Democracy" that would produce 50,000 planes and 20,000 tanksenough not only to make the U.S. armed forces the most powerfully equipped military juggernaut in history, but also to supply the needs of our allies. And although it was Japan, not Germany or Italy, that attacked us, Roosevelt nevertheless declared war on 
both countries and, for strategic reasons, devoted most of our military equipment and men to the European rather than the Asian theater.

The lives of the survivors of World War II were profoundly affected by the war, not only because of the loss of friends and siblings and the long interruption in the unfolding of their lives, but also because the war transformed the American economy. Techniques of production developed during the war and a profound appreciation of the new role of science in industry ushered in a quarter of a century of unprecedented economic growth. There was also a vast expansion of higher education, financed by the G.I. Bill of Rights, that provided the personnel for the immense expansion of research throughout the sciences, including the biomedical sciences and the social sciences.

Although the U.S. Army remained segregated throughout the war, it fought against the Nazis under the banner of the new anthropology developed by Franz Boas and his associates, which held that racial differences were superficial and that all human beings were essentially equal. Having imbibed the new ethic of equality, and stirred by the determined efforts of returning black soldiers and other participants in the emerging black civil rights movement that gained new prominence with Martin Luther King Jr.'s inspiring speech on the steps of the Lincoln Memorial in Washington, many in my cohort joined in the long fight to end segregation and Jim Crow.

The third cohort is the one born between 1980 and 1990. Since this is the cohort of Cornell's current undergraduate student body, I will not describe the context of your lives. After all, you have lived through it. I hope you will not object, however, if I refer to you as the cohort of IT and of the War against Terrorism. I should also like to mention one fact with which you may not be familiar. The average income of the households into 
which you were born is more than 13 times greater than the average income of the households into which the Civil War generation was born. Or to put it in a slightly different way, you consume as much in four weeks as the first cohort consumed in a whole year.

\section{The Health and Longevity of the Civil War Cohort}

The first thing to be noted about the times of the cohort that fought the Civil War is that nearly a quarter of their number died in infancy and that a total of 40 percent died before age 15. Less than half lived to see their thirtieth birthday. By contrast, less than 11 percent of my cohort died before age 15 and more than half of my cohort was still alive at the dawn of the new millennium. As for your cohort, less than one and a half percent died before age 15. Most of these deaths were in infancy due to poor fetal development. As for your prospects, there is a good chance that half of you will live to celebrate your hundredth birthday, and most of you will be in good health for the rest of your lives. I will explain the basis for this optimism a little later.

Life was not only short for the Civil War cohort, it was also nasty by the standards of my generation. As youngsters, members of the first cohorts were frequently severely ill with respiratory and gastrointestinal diseases that, even if they survived them, took a heavy toll on their subsequent health and made them victims of chronic, lifelong, conditions. Of those who lived to volunteer for the Union Army, one-quarter were rejected for chronic disabilities. Even in their teens, one out of six suffered from severe disabilities and by their late thirties more than half were disabled. Despite their relatively young ages, cardiovascular diseases (mainly rheumatic) accounted for 11 percent of the rejections; hernias 12 percent; eye, ear and nose diseases 7 percent; tuberculosis and other 
respiratory diseases 7 percent; tooth and gum diseases 8 percent. Most of the rest of the rejections were due to orthopedic conditions and general debility.

The many premature deaths of the Civil War cohort reflected both their high exposure to severely debilitating diseases and their chronic malnutrition, as reflected in their poor weights throughout the life cycle. Although calories were more abundant in the United States than in Europe, poor absorption and heavy labor often prevented ingested nutrients from being utilized for physiological development. As a result, teenagers were severely stunted by the standards of your generation. On average, males were about 4 inches shorter at maturity than today. Among children raised in the urban slums, the deficit was about half a foot. The impoverished were not only stunted but "wasted," which means that their weight was inadequate for their height. By current standards, one out of six young adults was dangerously underweight.

Environmental perils were much more severe than today. The idyllic countryside was, by current standards, exceedingly perilous. Malaria was everywhere in the South and was, in the 1840s and 1850s, endemic as far north as Madison, Wisconsin. "Fevers" were widespread complaints among farmers, who had no choice but to work through them. Other common diseases included typhoid, typhus, and "lockjaw." Farmers were also plagued by a variety of orthopedic complaints brought on by heavy manual labor that made them, in the words of one poet, "brother to the ox."

The countryside of the Union Army cohort was idyllic only by comparison with the cities. In such large cities as Boston, New York, and Philadelphia, life expectancy at birth in 1830 was just 24 years, about 10 years less than that of Southern slaves. In the worst slums, half of all infants died. Tuberculosis was the great killer disease of cities, 
accounting for more than one of four deaths in New York City. And it remained the greatest urban killer through the end of the nineteenth century.

Despite their poor health, members of the Union Army cohort had to endure exceedingly long hours of work. They labored from dawn to dusk for six and a half days per week or about 78 hours per week. Regular vacations were unknown for the laboring classes. Even after allowing for time lost due to illness, prime-aged workers put in about 3600 hours per year, more than twice the current standard. Long working hours were also the standard for women, who usually rose before their husbands, and went to sleep after them.

Despite their perilous beginnings, things did improve for the survivors of the Union Army cohort as their century wore on. Wages and income rose generally, although these advances were offset by the increasing severity of business cycles. Hours of labor did decline, and by the end of the century, it was the eight-hour day that adorned the banners of radical labor. However, the relative position of labor may have worsened. The gap in life-expectancy between the poor and the rich, between black and white, increased during the last third of the nineteenth century. Rapid urbanization created severe new problems of public health that were not solved until well into the twentieth century.

\section{The Health and Longevity of the World War II Cohort}

The start of life was much better for my cohort than for the Union Army cohort. Not only did fewer of us die early in life, but the survivors have also lived longer and healthier lives than the members of the first cohort. Most of us have managed to live past age 60 without developing severe chronic diseases. And the great majority of us in our seventies are still free of the disabilities that afflicted the earlier cohort. The 
overwhelming majority have good to excellent health, live independent lives, and are socially active.

Why are today's elderly doing so much better than the elderly of the Union Army cohort? While this question is still a major issue of biodemographic research, there is much evidence pointing to the crucial role of improvements in the environment, especially at early ages. One of the major findings of the biodemographic research of the past two decades is that the severity and extent of chronic diseases at middle and late ages are, to a large extent, due to environmental insults at early ages, including in utero. My cohort differs from the Union Army cohort in the extent to which we escaped the intrauterine and early childhood hazards that so severely afflicted them. As a result, my cohort developed far more robust vital organ systems, which may be thought of as enhanced physiological capital.

Much of this improvement is due to a process that Dora Costa (of MIT) and I call "technophysio evolution." Technophysio evolution is the result of a synergism between technological advances and physiological improvements that has produced a form of human evolution that is biological but not genetic, rapid, culturally transmitted, and not necessarily stable. This process is still ongoing in both rich and developing nations.

The theory of a nexus between environmental insults in utero or at early postnatal ages and the risk of chronic conditions 50 years later calls attention to the rapid improvement in the environment between 1890 and 1950. Chief among these improvements was the cleaning up of the water supply by switching from wells contaminated by sewage to water purified by chlorination and other techniques. The early decades of the twentieth century also witnessed great advances in the improvement of the 
milk supply, which was contaminated by bovine tuberculosis and high bacteria counts due to the poor handling of milk by farmers and dairies. Much progress was made by switching from raw to pasteurized milk, a transition that took several decades to complete.

Still another aspect of the improvement in the urban environment was the solution to the "horse problem." Today we tend to focus on the negative role of the automobile because of its effect on levels of greenhouse gases. But in the early days of the twentieth century, automobiles were greeted as a blessing because they permitted large cities to escape from the diseases caused by the pulverized horse manure that contaminated the atmosphere and carried deadly pathogens.

My cohort has also benefited from the egalitarian advances of the twentieth century. The strength of these advances during the first four decades of the century has been badly underestimated as a result of the tendency of economists to focus on such conventional measures as the share of income held by the richest 5 or 10 percent of households, which remained relatively constant between 1900 and 1940. However, measures of health and longevity tell a different story. The sharp decline in the infant mortality rate, for example, was due mainly to the gains of the poor, not of the rich or the middle classes. In the largest 24 American cities in 1900, the infant mortality rates of the impoverished neighborhoods were several times as high as those in the most prosperous neighborhoods. More than 80 percent of that gap disappeared during the next five decades. Indeed, nearly all of the decline in the infant death rate between 1900 and 1950 was due to the elimination of class disparities. Current disparities are much smaller than 
they used to be. From the perspective of 1900, we are currently engaged in fine-tuning, not in gross corrections.

Another novel aspect of the life and times of my generation is the great increase in the availability of leisure. Even toward the end of the nineteenth century, the typical household head worked a 3,100-hour year, which allowed less than two hours per day for leisure, including Sundays. Today the typical household head spends more time at leisure than at work. Moreover, the range and quality of leisure time activities, especially for lower income groups, has greatly improved. When early retirement is taken into account, leisure time has quadrupled.

Still another aspect of the life and times of my cohort is the small share of household income spent on food, clothing, and shelter. A century ago, these three items accounted for 75 percent of all expenditures. Today they account for just 13 percent. Most expenditures today are on health care, education, and leisure. We spend more on health care not because we are sicker than past generations, but because we are richer and demand the best treatment that money can buy. And the bill for this health care is financed overwhelming by employers or, in the case of Medicare and Medicaid, by taxes.

\section{Prospects for the Health and Longevity of the Cohort of IT and the War against Terrorism}

Did my forecast that your generation has a 50-50 chance of living to a hundred startle you? It should. That is the normal reaction. Nobody in 1900 could have conceived of the possibility that life expectancy at the end of the century would be over 75 . In the late 1920s, the chief actuary of the Metropolitan Life Insurance Company put a cap of 65 years on the life expectancy of both men and women. In 1936 he collaborated with the 
leading mathematical demographer of the first half of the twentieth century to publish a revised upper limit of 70 years. More recently, a leading gerontologist set an upper limit of 85 years plus or minus 7 years. Generally speaking, these caps tend to be in the range of 5 to 10 years beyond the observed life expectancy at the time the forecast was made.

Over the course of the twentieth century, life expectancy increased by about 3 years per decade. Since your cohort is six decades later than mine, a continuation of past experience suggests that the median length of life in your cohort will turn out to be about 100. Some experts argue that the experience of the twentieth century cannot be replicated, because those gains came mainly from eliminating the high mortality rates of infants and children. However, as I have noted, it is the improvement in health at younger ages that argues for improvement of mortality rates at older ages. Indeed, the average age at onset of the principal chronic diseases has been delayed by about 10 years between the first and second cohorts. Moreover, the decline in disabilities among the elderly has accelerated in recent years. Between 1984 and 2000, the rate of decline in disabilities increased by 50 percent.

I expect the decline in chronic conditions and disabilities to continue, partly because of continuing improvements in human physiology, and partly because we have the economic resources and the inclination to invest heavily in health improvements. Indeed, we are far richer than current measures of gross domestic product indicate. Earlier, I said that the average income of the households into which you were born was 13 times greater than that of the Civil War cohort. That measure is much too low. It badly underestimates U.S. economic growth during the past century because it does not take into account improvements in the quality of output, especially in such services as 
education and health care. Children in secondary schools are taught more today than postgraduate college students used to be taught a generation ago, let alone two generations ago.

Even more dramatic are the improvements in health care. Not only has the average age at onset of disabilities been delayed by a decade or so, but once they do appear, there are now numerous effective interventions. Hernias, which used to be permanent and exceedingly painful conditions afflicting one out of every four males, can now be repaired by a surgical procedure that in the United States requires hospitalization for only 23 hours. Other areas where medical interventions have been highly effective include genito-urinary conditions, control of hypertension and reduction in the incidence of stroke, replacements of knee and hip joints, curing of cataracts, and chemotherapies that reduce the incidence of osteoporosis and heart disease.

Yet most of these great advances in health care and education are overlooked in accounts of gross domestic product (GDP), because the values of these sectors are measured by inputs instead of by output. An hour of a doctor's time is considered no more effective today than an hour of a doctor's time was half a century ago, before the age of antibiotics and modern surgery. It has recently been estimated that improvements in health care, if properly measured, are at least twice the cost of health care, but such calculations have not yet made their way into the GDP accounts. In the case of the United States, my own rough estimates indicate that allowance for such factors as the increase in leisure time, the improvements in the quality of health care, and the improvements in the quality of education would come close to doubling the U.S. annual growth rate of per capita income over the past century (from 2.0 to 3.6 percent per annum). 
What is the implication of these statistics for understanding our capacity to invest in health improvements? If we use the conventional measure of growth, the real per capita income in 2000 was 7 times greater than it was in 1900. However, if the adjusted measure is used, real per capita income was 34 times greater than in 1900. In other words, the resources available to improve health are 5 times greater than suggested by current national income accounts, if we choose to marshal them for that purpose.

I believe that the will to invest more heavily in good health is there. In 1929, we spent 3 percent of GDP on health care. Today, the figure is 15 percent, higher if we allow for unmeasured benefits. The long-term income elasticity of the demand for health care is 1.6, which implies that if we continue to grow at past rates, the share of income expended on health care could reach 30 percent of GDP by 2030 .

Will this vast expansion of expenditures on health care pay off? There are reasons to be optimistic here also. Not only is the onset of disabilities a decade or so later, not only is the rate of delay in disabilities accelerating, but disabilities, once they appear, are milder and easier to treat. Technophysio evolution appears to be making us better candidates for evolving medical interventions. Moreover, the outlook for new and more effective technologies to deal with chronic disabilities is very promising, not only in drug therapies, but also in the marriage of biology and microchip technology. Indeed, some devices that combine living cells and electronics to replace failed organs are already at the stage of human trials. Somewhat further off, but even more promising, are advances in genetic engineering that will produce cures for what are now untreatable diseases. The future health of your generation is quite bright, provided that you adopt an appropriate life-style to go with the new technological opportunities. 